\title{
Type 1 diabetes susceptibility determined by HLA alleles and CTLA-4 and insulin genes polymorphisms in Brazilians
}

\author{
Suscetibilidade ao diabetes tipo 1 determinada por alelos de HLA \\ e polimorfismos nos genes CTLA-4 e insulina em brasileiros
}

Alessandro Clayton Souza Ferreira', ${ }^{1,2}$, Karina Braga Gomes³, Ivan Barbosa Machado Sampaio4, Vanessa Cristina de Oliveira ${ }^{1,2}$, Victor Cavalcanti Pardini',2, Ana Lucia Brunialti Godard'

\begin{abstract}
Introduction:Type 1A diabetes mellitus (T1ADM) is a multifactorial disease in which genetic and environmental aspects are important to its development. The association of genetic variations with disease has been demonstrated in several studies; however, the role of some gene loci has not yet been fully elucidated. Objective:To compare the frequency of $H L A$ alleles and polymorphism in CTLA-4 and insulin genes in Brazilians withT1ADM and individuals without the disease, as well as to identify genetic markers that are able to discriminate between diabetic and non-diabetic individuals. Methods: The presence of HLADQB1, DQA1 and DRB1 alleles, as well as the $-2221 \mathrm{Mspl}$ polymorphism in the insulin gene and $49 \mathrm{~A} / \mathrm{G}$ in the $C T L A-4$ gene were identified by the "Time-resolved fluorometer" technique after hybridization with probes labeled with Eu (III) / Sm (III) and Tb (III). Results: The DQB1 ${ }^{*} 0302$ and DQA1 *03 alleles were identified as predisposed to T1ADM, and the DQB $1{ }^{*} 0301$ allele presented a protective effect against the disease. The DQA1 label proved to be able to differentiate between $71.13 \%$ of the diabetic and non-diabetic individuals. This value increased to $82.47 \%$ when the DQB1 label was added. No significant difference in the frequency of polymorphisms in the insulin and CTLA-4 genes was observed between the two groups. Conclusions: The genetic markers that best characterized and discriminated diabetic and non-diabetic individuals were the HLA DQA1 and DQB1.alleles. Arq Bras Endocrinol Metab. 2009;53(3):368-73.

Keywords

T1ADM; HLA; CTLA-4; insulin gene; discriminant factor analysis
\end{abstract}

\section{RESUMO}

Introdução: 0 diabetes melito tipo 1 (T1ADM) é uma doença multifatorial em que os aspectos genéticos e ambientais são importantes para o seu desenvolvimento. A associação das variações genéticas com a doença tem sido demonstrada em vários trabalhos, no entanto, o papel de alguns locos gênicos não foi ainda completamente elucidado. Objetivos: Comparar a frequência de alelos do HLA e polimorfismos nos genes CTLA-4 e insulina em brasileiros com T1ADM e indivíduos sem a doença, além de identificar marcadores gênicos que sejam capazes de discriminar indivíduos diabéticos e não diabéticos. Métodos: A presença dos alelos de HLA DQB1, DQA1 e DRB1, bem como dos polimorfismos -2221 Mspl no gene da insulina e 49 A/G no gene CTLA-4, foram identificados por meio da técnica Time-resolved fluorometer, após hibridização com sondas marcadas com Eu (III)/Sm (III) eTb (III). Resultados: Os alelos DQB1*0302 e DQA $1{ }^{*} 03$ foram identificados como sendo de predisposição aoT1ADM, e o alelo DQB1*0301 mostrou um efeito protetor à doença. Analisando somente o marcador DQA1, este mostrou ser capaz de diferenciar $71,13 \%$ dos indivíduos entre diabéticos e não diabéticos, cujo valor aumentou para $82,47 \%$ quando adicionado o marcador DQB1. A frequência dos polimorfismos nos genes da insulina e CTLA-4 não mostrou diferença significativa entre os dois grupos estudados. Conclusões: Os marcadores genéticos que melhor caracterizaram e discriminaram diabéticos e não diabéticos foram os alelos de HLA DQA1 e DQB1. Arq Bras Endocrinol Metab. 2009;53(3):368-73.

Palavras-chave

T1ADM; HLA; CTLA-4; gene da insulina; análise fatorial discriminante 


\section{INTRODUCTION}

Type 1A diabetes mellitus (TIADM) results from the cell-mediated autoimmune destruction of pancreas $\beta$-cells ( 1 ). Although TIADM has always been recognized as a childhood disease, recent epidemiological studies have indicated that the incidence is comparable in adults (2). There is an enormous variation in the worldwide incidence of TIADM. In Finland, the incidence is 30 to 40 per 100,000 inhabitants; but in Japan this incidence is 1 per 100,000 inhabitants $(3-5)$. The incidence in the Brazilian population was estimated at 7.6 per 100,000 inhabitants $(6,7)$.

Susceptibility to TIADM involves both genetic and environmental components. Genetic associations with TlADM were observed almost 30 years ago (8), but the full knowledge of genetically susceptible loci has not been fully elucidated. The HLA region accounts for approximately $50 \%$ of the genetic susceptibility to TIADM, suggesting that the sum of the effects of other susceptible loci is nearly as great as the HLA effect (8-10).

There are several candidate gene regions for TlADM susceptibility. However, many of these regions were associated with TIADM in only a portion of the populations studied (11). One of them is the cytotoxic T lymphocyte-associated antigen-4 (CTLA-4) gene, localized on the $2 \mathrm{q} 33$ chromosome region. It encodes the $\mathrm{T}$ cell receptor involved in the control, proliferation and $\mathrm{T}$ cell apoptosis. This gene is a strong candidate for $\mathrm{T}$ cell-mediated autoimmune diseases like TIADM $(12,13)$. In this gene, the main polymorphism is localized in exon 1 at position $49(\mathrm{~A} \rightarrow \mathrm{G})$, which encodes threonine (Thr) or alanine $(\mathrm{Ala})$, respectively $(14,15)$. The CTLA-4 $\mathrm{G}$ allele has been associated with TIADM in many populations (16-19). The insulin (INS) gene, located on human chromosome $1 \mathrm{lp} 15.5$, is another gene in which some polymorphisms in the promoter region have been reported to possess a strong association with TIADM $(20,21)$. The association of the $\mathrm{C} / \mathrm{T}$ polymorphism of the insulin gene -2221 MspI with the $49 \mathrm{~A} / \mathrm{G} C T L A-4$ polymorphism may vary among populations, but the studies support the hypothesis that insulin CC and CTLA-4 GG genotypes are an independent and clearly significant risk for developing type 1 diabetes (22-25).

In the Brazilian population, which is characterized by its great heterogeneity (24), only $H L A$ has been studied in association with TlADM (25-31). Volpini and cols., using the affected-family-based control (AFBAC) method to study 56 Southeastern Bra- zilian families, showed increased frequencies of the $\mathrm{DRBI}^{*} 03-\mathrm{DQA1}{ }^{*} 0501-\mathrm{DQB1}{ }^{*} 02$ and $\mathrm{DRBI}{ }^{*} 0401-$ DQAI ${ }^{*} 03-\mathrm{DQBI}{ }^{*} 0302$ haplotypes in the patient group and a lack of a significant protective effect of the DRBI*1501-DQAI*0102-DQBI*0602 haplotype. An apparent protection conferred by the DRBI*13$\mathrm{DQB1}{ }^{*} 0301, \mathrm{DRB1}{ }^{*} 11-\mathrm{DQB1}{ }^{*} 0301$, and $\mathrm{DRB}{ }^{*} 01-$ DQB1*0501 haplotypes was reported (28).

In view of the evidence that in some types of polymorphism in insulin, CTLA-4 genes and HLA haplotypes are associated with the development of TIADM, in spite of the fact that only one study evaluated these polymorphisms in the Brazilian population (29), the aim of the present study was to expand the analysis of these genes in the Brazilian population and to find a marker or a set of markers that would best discriminate the TIADM susceptibility.

\section{METHODS}

\section{Subjects}

A total of 49 Brazilian patients with clinical and laboratory diagnoses of type 1 diabetes were screened for the presence of IA2 and GAD autoantibodies. The individuals had a mean age of $15.76 \pm 1.91$ and a diabetes diagnosis age of $9.75 \pm 4.15$. For the non-diabetic control group, 48 individuals without diabetes and no family history of the disease were included. These individuals had a mean age of $31.2 \pm 5.12$. Brazilian individuals over 25 years of age were evaluated for the control, so we were more confident that they would not develop type 1 diabetes. All of subjects provided a written informed consent, and this study was approved by the local ethical committee (COEP-UFMG).

\section{Genotyping of HLA DQB1, DQA1 and DRB1 alleles}

DNA was extracted from peripheral blood using the PUREGENE $^{\oplus}$ kit. The alleles were detected using the DELFIA $^{\oplus}$ technology $\left(\right.$ Walac $\left.\mathrm{Oy}^{\oplus}\right)$. One microgram of genomic DNA was used as a substrate for the PCR (Polymerase Chain Reaction). For the amplification of the HLA region, the following primers were used: 5' GCA TGT GCT ACT TCA CCA ACG, 3'bio-CCT TCT GGC TGT TCC AGT ACT for DQBI; 5' bioTAT GGT GTA AAC TTG TAC CAGT, 3' GGT AGC AGC GGT AGA GTT G for DQAl and 5' GTT TCT TGG AGC AGG TTA AAC A, 3'bio-CTC GCC GCT GCA CTG TGA for DRB1. The time-resolved fluorimetric detection of the alleles was performed on the 
1420 VICTOR $^{\mathrm{TM}}$ Time-resolved fluorometer after hybridization with a panel of labeled chelated lanthanide probes $-\mathrm{Eu}(\mathrm{III}) / \mathrm{Sm}(\mathrm{III})$ and $\mathrm{Tb}(\mathrm{III})(32,33)$

\section{Genotyping of CTLA-4 and INS gene polymorphisms}

The same technology described for the $H L A$ alleles was used for detection of the $49 \mathrm{~A} / \mathrm{G}$ polymorphism at exon 1 of the CTLA-4 gene and the polymorphism at 2221 upstream from the INS gene (-2221 MspI). The following primers were used for the PCR reaction: 5' TTC CTG AAG ACC TGA ACA CC, 3' bio-AAT GAC TGC CCT TGA CTG CT for CTLA4 and 5' ACC CCA CTA CAC GCT GCT G and 3' bio-CCC TTC AGA GAC ACC CCC A for the -2221 MspI polymorphism in the INS gene. The time-resolved fluorimetric detection of the alleles was performed on the 1420 VICTOR $^{\mathrm{TM}}$ Time-resolved fluorometer after hybridization with a panel of labeled chelated lanthanide probes $-\mathrm{Eu}(\mathrm{III}) / \mathrm{Sm}(\mathrm{III})$ and $\mathrm{Tb}(\mathrm{III})(33,34)$.

\section{Statistical analysis}

Data analysis was performed using the GENEPOP software. An Odds Ratio was calculated according to Woolf's method and, by convention, presented as relative risk. A discriminant factor analysis was performed using the genotyping results to determine whether the two groups, diabetic and non-diabetic, could be distinguished.

\section{RESULTS}

Allelic frequency and relative risk were determined for all the alleles found (Tables 1, 2 and 3). For the polymorphisms of the CTLA-4 (Table 2) and insulin gene (Table 3), the genotype frequencies were determined in addition to the allele frequencies.

It could be clearly observed that the main predisposition alleles in the samples were $\mathrm{DQB1}{ }^{*} 0302(\mathrm{RR}$ $=3.84)$ and $\mathrm{DQAl} * 03(\mathrm{RR}=3.0)$. Similar results have been described in the Brazilian population and in other populations $(27,28,29,30,31)$. A significant protective effect of the $\mathrm{DQB1}{ }^{*} 0301$ allele, which had been described in several populations, was also observed $(4,27,28,29,30,31)$. Significant valueswere not obtained for $\mathrm{DRBl}^{*} 04$ when the $\mathrm{DRB}^{*} 0401, \mathrm{DRBl}{ }^{*} 0402$, $\mathrm{DRBI}^{*} 0403, \mathrm{DRB1}{ }^{*} 0404$ and $\mathrm{DRBl}{ }^{*} 0405$ alleles were analyzed. Therefore, an analysis for the presence or absence of $\mathrm{DRBl}{ }^{*} 04$ was performed. A relative risk of 3.34 was found $(\mathrm{p}<0.0009)$. It should be emphasized that both the $49 \mathrm{~A} / \mathrm{G}$ CTLA-4 and the -2221 MspI polymorphisms, which was previously shown to be an important risk factor for diabetes development in other populations $(22,35-37)$, were not statistically significant for the genetic predisposition for type 1 diabetes in the subjects analyzed.

\begin{tabular}{|c|c|c|c|c|}
\hline HLA alleles & $\begin{array}{c}\% \text { IDDM } \\
(2 n=98)\end{array}$ & $\begin{array}{l}\% \text { Control } \\
(2 n=96)\end{array}$ & $\begin{array}{c}\text { Relative } \\
\text { Risk }\end{array}$ & $p$ value \\
\hline $\mathrm{DQB1*02}$ & 43.88 & 14.58 & 4.66 & NS \\
\hline $\mathrm{DQB} 1{ }^{\star} 04$ & 2.04 & 2.08 & 1.00 & NS \\
\hline DQB1*05 & 1.02 & 0.0 & - & NS \\
\hline $\mathrm{DQB1}$ 0301 & 5.10 & 25.0 & 0.16 & $<0.05$ \\
\hline $\mathrm{DQB1*0302}$ & 25.51 & 8.33 & 3.84 & $<0.05$ \\
\hline DQB1*0303 & 0.0 & 2.08 & 0.0 & NS \\
\hline DQB1*0304 & 1.02 & 1.04 & 1.0 & NS \\
\hline $\mathrm{DQB1}{ }^{*} 0501$ & 15.31 & 19.79 & 0.75 & NS \\
\hline $\mathrm{DQB1*0502}$ & 1.02 & 2.08 & 0.49 & NS \\
\hline $\mathrm{DQB1*0503}$ & 0.0 & 5.21 & 0.0 & NS \\
\hline $\mathrm{DQB1*} 0601$ & 0.0 & 1.04 & 0.0 & NS \\
\hline $\mathrm{DQB} 1{ }^{\star} 0602$ & 1.02 & 9.38 & 0.1 & NS \\
\hline $\mathrm{DQB1*0603}$ & 1.02 & 5.21 & 0.19 & NS \\
\hline $\mathrm{DQB} 1{ }^{\star} 0604$ & 3.06 & 4.17 & 0.74 & NS \\
\hline $\mathrm{DQA1}{ }^{*} 03$ & 27.55 & 9.37 & 3.0 & $<0.009$ \\
\hline $\mathrm{DQA1*05}$ & 36.65 & 19.79 & 1.68 & NS \\
\hline $\mathrm{DQB1*0201}$ & 5.10 & 11.45 & 0.46 & NS \\
\hline $\mathrm{DRB} 1{ }^{*} 0401$ & 4.16 & 0.0 & - & NS \\
\hline DRB1*0402 & 6.12 & 3.06 & 2.03 & NS \\
\hline DRB1*0403 & 1.02 & 1.02 & 1.0 & NS \\
\hline DRB1*0404 & 6.12 & 3.06 & 2.03 & NS \\
\hline $\mathrm{DRB} 1 * 0405$ & 11.22 & 2.04 & 5.55 & NS \\
\hline DRB1*04 & 53.06 & 16.0 & 3.34 & $p<0.0009$ \\
\hline
\end{tabular}

RR: relative risk; NS: non-significant; IDDM: type 1 diabetes mellitus.

The results were considered significant when $p<0.05$.

Table 2. Distribution of allele and genotype frequencies for $49 \mathrm{~A} / \mathrm{G}$ CTLA-4 in diabetic and normal individuals (non-diabetic)

\begin{tabular}{lcccc}
\hline Allele/genotype & \% IDDM & \% Control & RR & p value \\
\hline Allele frequencies & & & & \\
A & 73.47 & 67.71 & 1.34 & NS \\
G & 26.53 & 32.29 & 0.75 & NS \\
Genotype frequencies & & & & \\
AA & 53.06 & 45.83 & 1.38 & NS \\
AG & 40.81 & 43.75 & 0.88 & NS \\
GG & 6.12 & 10.41 & 0.57 & NS \\
\hline
\end{tabular}

RR: relative risk; NS: non-significant; IDDM: type 1 diabetes mellitus.

The results were considered significant when $p<0.05$. 
Table 3. Distribution of allele and genotype frequencies of the $-2221 / \mathrm{Mspl}$ polymorphism at the 11p15.5 region in diabetic patients and normal individuals (non-diabetic)

\begin{tabular}{lcccc}
\hline Allele/genotype & \% IDDM & \% Controls & RR & $\mathbf{p}$ - value \\
\hline Allele frequencies & & & & \\
C & 87.80 & 84.40 & 1.29 & NS \\
T & 12.2 & 15.6 & 0.77 & NS \\
Genotype frequencies & & & & \\
CC & 79.59 & 68.75 & 1.8 & NS \\
CT & 20.40 & 31.75 & 0.56 & NS \\
TT & 0.0 & 0.0 & - & - \\
\hline
\end{tabular}

RR: relative risk; NS: non-significant; IDDM: type 1 diabetes mellitus.

The results were considered significant when $p<0.05$.

\section{Discriminant factor analysis}

The discriminant factor analysis showed that the markers that best characterized and discriminated between the two groups were DQAl and DQBl, in this order. The remaining markers were not helpful in discriminating diabetic and non-diabetic individuals. It was possible to correctly distinguish diabetic from non-diabetic individuals in $71.13 \%$ of the subjects by analyzing only the DQAl marker. This percentage increased to $82.47 \%$ when the DQBl marker was included. The other markers $\left(\mathrm{DRB}^{*} 04, C T L A-4\right.$ and $\left.-2221 / M s p \mathrm{I}\right)$ did not increase this parameter when they were added to the discriminant factor analysis.

\section{DISCUSSION}

The great variability in the incidence of type 1 diabetes in the world can be partly explained by differences in the frequencies of the alleles that predispose for the disease. The analysis of the $H L A$ frequencies confirmed the importance of the $\mathrm{DQBl}{ }^{*} 0302$ and $\mathrm{DQAl}{ }^{*} 03$ alleles in the predisposition for type 1 diabetes. The importance of the $\mathrm{DQB1}{ }^{*} 0301$ in the protection against the development of the disease can be observed, since it was more common in non-diabetic individuals.

As for $H L A \mathrm{DRB}^{*} 04$, when each allele $\left(\mathrm{DRB}^{*} 0401\right.$, $\mathrm{DRB}^{*} 0402, \mathrm{DRB}^{*} 0403, \mathrm{DRB}^{*} 0404$ and $\mathrm{DRB}^{*} 0405$ ) was analyzed separately, no significant values were observed. This observation is probably due to the limited number of individuals in the study. However, the determination of presence or absence of $H L A D R{ }^{*} 04$ led to significant results, suggesting that the analysis of $\mathrm{DRB1}{ }^{*} 04$, without differentiating the several alleles, is a good tool for determining the relative risk for development of diabetes.
The discriminant factor analysis was extremely important in this work. The objective of this analysis was to verify whether the two groups, diabetic and nondiabetic, were really distinct between themselves based on the distribution of alleles that predispose for diabetes, and also to verify, when defining the groups, which markers or set of marker among those markers studied could best discriminate between the groups.

The results showed that HLA DQAl alone can correctly classify $71.13 \%$ of the individuals into diabetic and non-diabetic groups. This value is denominated a well-classified percentage. When the HLA DQBI was introduced into the analysis, the well-classified percentage increased to $82.47 \%$. The remaining markers analyzed did not increment this value, since there was an overlapping in the classification. Noticeably, since type 1 diabetes is a complex and multifactorial disease, where not only genetic but also environmental factors contribute for its development, there are individuals that exhibit the predisposition alleles and do not show the clinical symptoms, and there are those who do not show the predisposition alleles but are clinically diabetic. For these reasons, the above-mentioned well-classified percentage should not be absolute.

The analyses of the $49 \mathrm{~A} / \mathrm{G}$ CTLA-4 and the $-2221 /$ MspI polymorphism of the insulin gene, contrary to expectations, did not reveal any association with type 1 diabetes in the individuals analyzed. Allele and genotype frequencies of the two polymorphisms are similar in the affected and non-affected individuals. This fact is particularly surprising regarding the 49 A/G CTLA-4 gene polymorphism since it is strongly associated with diabetes in several populations around the world $(22,35-37)$. Although the CTLA-4 gene is strongly associated with autoimmune diseases, specially those mediated by T-cells, the lack of this association has already been described in Brazilian patients with autoimmune hepatitis and primary biliar cirrhosis $(38,39)$, contrary to the observations in several studies carried out in other populations $(40,41)$.

It is worth noticing that, in the present study, the HLA DQAl allele was more important for distinguishing diabetic and non-diabetic individuals than DQBI and DRB1. The results confirmed the importance of the $H L A$ region for the development of type 1 diabetes in Brazilian individuals and also suggest that $49 \mathrm{~A} / \mathrm{G}$ at the CTLA-4 gene and $-2221 / \mathrm{MspI}$ polymorphisms at the INS gene, in principle, were not so important to the genetic predisposition to the disease. However, 
complementary studies are necessary for evaluating whether other previously-described polymorphisms at the CTLA-4 and insulin genes collaborate for predisposition to the disease.

Many studies have presented new therapies for treating and avoiding the onset of type 1 diabetes in animal models and in humans $(42-45)$. We believe that the correct identification of individuals with genetic predisposition for the disease can be a useful tool for prescribing new treatments in the near future.

Disclosure: no potential conflict of interest relevant to this article was reported.

\section{REFERENCES}

1. Atkinson MA, Maclaren NK. The pathogenesis of insulin-dependent diabetes mellitus. N. Engl J Med. 1994;331:1428-36.

2. Onkamo P, Vaananan $S$, Karvonen M,Tuomilehto J. Worldwide increase in incidence of type I diabetes - the analysis of the data on published incidence trends. Diabetologia. 1999;42:1395-03.

3. Tuomilehto J, Virtala E, Karvonen M, Lounamaa R, Pitkaniemi $J$, Reunanen $A$, et al. Increase in incidence of insulin-dependent diabetes mellitus among children in Finland. Int $\mathrm{J}$ Epidemiol. 1995;24(5):984-92.

4. Thomson G, Valdes AM, Noble JA, Kockum I, Grote MN, Najman J, et al. Relative predispositional effects of HLA class II DRB1-DQB1 haplotypes and genotypes on type 1 diabetes: a meta-analysis. Tissue Antigens. 2007;70(2):110-27.

5. Abiru N, Kawasaki E, Eguch K. Current knowledge of Japanese type 1 diabetic syndrome.Diabetes Metab Res Rev. 2002;18(5):35766. Review.

6. Ferreira SR, Franco LJ, Vivolo MA, Negrato CA, Simoes AC, Ventureli CR. Population-based incidence of IDDM in the state of Sao Paulo, Brazil. Diabetes Care. 1993;16(5):701-4.

7. Lisboa HR, Graebin R, Butzke L, Rodrigues CS. Incidence of type 1 diabetes mellitus in Passo Fundo, RS, Brazil. Braz J Med Biol Res. 1998;31(12):1553-6.

8. Singal DP, Blajchman MA. Histocompatibility (HL-A) antigens, lynphotoxic antibodies and tissue antibodies in patients with diabetes mellitus. Diabetes. 1973;22(6):429-32.

9. Noble JA, Valdes AM, Cook M, Klitz W, Thomson G, Erlich HA. The role of HL-A class II genes in insulin-dependent diabetes mellitus: molecular analysis of 180 Caucasian, multiplex families. Am J Hum Genet. 1996;59(5):1134-48.

10. Davies JL, KawaguchiY, Bennett ST, Copeman JB, Cordell HJ, Pritcherd LE, et al. A genome-wide search for human type 1 diabetes susceptibility genes. Nature. 1994;371(6493):130-6.

11. Onegut-Gumuscu $S$, Concannon P. Mapping genes for autoimmunity in humans: Type 1 diabetes as a model. Immunol Rev. 2002;190:182-94.

12. Dariavach $P$, Mattei MG, Golstein $P$, Lefranc MP. Human Ig superfamily CTLA4 gene: chromosomal localization and identity of protein sequence between murine and human CTLA4 cytoplasmatic domains. Eur J immnogenet. 1998;18:1901-5.

13. Robey E, Allison JP. T-cell activation: integration of signals from the antigen receptor and costimulatory molecules. Immunol Today. 1995;16(7):306-9.

14. Gribben JG, Feeman GJ, Boussiotis VA, Rennert P, JellisCL, Greenfield $E$, et al. CTLA4 mediates antigen-specific apoptosis of human T Cells. Proc Natl Acad Sci USA. 1995;92(3):811-5.
15. Zalloua PA, Abchee A, Shbaklo H, ZreikTG, Terwedow H, Halaby G, Azar ST. Patients with early onset of type 1 diabetes have significantly higher GG genotype at position 49 of the CTLA4 gene. Hum Immunol. 2004;65(7):719-24.

16. Copeman JB, Cucca F, Heame CM, Cornall RJ, Reed PW, Renningen KS, et al. Linkage disequilibrium mapping of type I diabetes susceptibility gene (IDDM7) to chromosome 2q31-q33. Nat Gen. 1995;9(1):80-5.

17. Marron MP, Raffel LJ, Garchon H-J, Jacob CO, Serrano-Rios M, Martinez LMT, et al. Insulin dependent diabetes mellitus (IDDM) is associated with CTLA4 polymorphism in multiple ethnic groups. Hum Mol Gent. 1997;6:1275-82.

18. Kikuoka N, Sugihara S, Yanagawa T, Ikezaki A, Kim HS, Matsuoka $\mathrm{H}$, et al. T lymphocyte antigen 4 gene polymorphism confers susceptibility to type 1 diabetes in Japanese children: analysis of association with HLA genotypes and autoantibodies. Clin Endocrinol 2001;55(5):597-603.

19. Chistiakov DA, Savost'anov KV, Nosikov VV. CTLA4 gene polymorphisms are associated with, and linked to, insulin-dependent diabetes mellitus in a Russian population. BMC Genet. 2001;2(1):6.

20. Lucassen AM, Julier C, Beressi J-P, Boitard C, Froguet $P$, Lathrop $M$, et al. Susceptibility to insulin dependent diabetes mellitus maps to a $4.1 \mathrm{~kb}$ segment of DNA spanning the insulin gene and associated VNTR. Nature Genet. 1993;4:305-10.

21. Stead JDH, Buard J, Todd JA, Jeffreys AJ. Influence of allele lineage on the role of the insulin minisatellite in susceptibility to type 1 diabetes. Hum Mol Genet. 2000;9(20):2929-35.

22. Haller K, Kisand K, Nemvalts V, Laine AP, Ilonen J, Uibo R. Type 1 diabetes is insulin $-2221 \mathrm{Mspl}$ and CTLA-4 +49 A/G polymorphism dependent. Eur J Clin Invest. 2004;34(8):543-8.

23. Laine AP, Nejentsev S, Veijola R, Korpinen E, Sjoroos M, Simell O, et al. A linkage study of 12 IDDM susceptibility loci in the Finnish population. Diabetes Metab Res Rev. 2004;20(2):144-9.

24. Laine AP, Hermann R, Knip M, Simell O, Akerblom HK, Ilonen $J$. The human leukocyte antigen genotype has a modest effect on the insulin gene polymorphism-associated susceptibility to type 1 diabetes in the Finnish population. Tissue Antigens. 2004;63(1):72-4

25. Haller K, Kisand K, Pisarev H, Salur L, Laisk T, Nemvalts $V$, et al. Insulin gene VNTR, CTLA-4 +49A/G and HLA-DQB1 alleles distinguish latent autoimmune diabetes in adults from type 1 diabetes and from type 2 Diabetes group. Tissue Antigens. 2007;69(2):121-7.

26. Alves-Silva J, da Silva Santos M, Guimaraes PE, Ferreira AC, Bandelt HJ, Pena SD, et al. The ancestry of Brazilian mtDNA lineages. Am J Hum Genet. 2000;67(2):444-61.

27. Fernandes AP, Louzada-Junior P, Foss MC, Donadi EA. HLA-DRB1, DQB1, and DQA1 allele profile in Brazilian patients with type 1 diabetes mellitus. Ann NY Acad Sci. 2002;958:305-8.

28. Volpini WM, Testa GV, Marques SB, Alves LI, Silva ME, Dib AS, et al. Family-based association of HLA class II alleles and haplotypes with type I diabetes in Brazilians reveals some characteristics of a highly diversified population. Hum Immunol. 2001;62(11):1226-33.

29. Hauache OM, Reis AF, Oliveira CS, Vieira JG, Sjöroos M, llonen J. Estimation of diabetes risk in Brazilian population by typing for polymorphisms in HLA-DR-DQ, INS and CTLA-4 genes. Dis Markers. 2005;21(3):139-45.

30. Marques SB, Volpini W, Caillat-Zucman S, Lieber SR, Pavin EJ, Persoli LB. Distribution of HLA-DRB1 alleles in a mixed population with insulin-dependent diabetes mellitus from the southeast of Brazil. Braz J Med Biol Res. 1998;31(3):365-8.

31. Eizirik DL, Monteiro CM, Voltarelli JC, Foss MC. Frequency of HLA antigens in a Brazilian type I diabetic population. Braz J Med Biol Res. 1987;20(5):533-7. 
32. Gomes MB, Ruzany F, Quadra AA, Sarno EN, Arduino F. Histocompatibility antigens and insulin-dependent diabetes: a study of 20 Brazilian families. Braz J Med Biol Res. 1981;14(6):379-81.

33. Soini $E$, Kojola H. Time-resolved fluorometer for lanthanide chelates. A new generation of non-isotopic immunoassays. Clin. Chem. 1983;29:65-8.

34. Hemmilä I, Dakubu S, Mukkala VM, Siitari H, LövgrenT. Europium as a label in time-resolved immunofluorometric assays. Anal. Biochem. 1984;137:335-43.

35. Turpeinen $H$, Laine AP, Hermann R, Simell O, Veijola R, Knip M, et al. A linkage analysis of the CTLA4 gene region in Finnish patients with type 1 diabetes. Eur J Immunogenet. 2003;30(4):289-93.

36. LeeYJ, Lo FS, Shu SG, Wang CH, Huang $\mathrm{CY}$, Liu HF, et al.The promoter region of the CTLA4 gene is associated with type 1 diabetes mellitus. J Pediatr Endocrinol Metab. 2001;14(4):383-8.

37. Bouqbis L, Izaabel $H$, Akhayat $O$, Perez-Lezaun A, Calafell $F$, Bertranpetit J, et al. Association of the CTLA4 promoter region (-1661G allele) with type 1 diabetes in the South Moroccan population. Genes Immun. 2003;4(2):132-7.

38. Bittencourt PL, Palacios SA, Farias AQ, Abrantes-Lemos CP, Cancado EL, Carrilho FJ, et al. Analysis of major histocompatibility complex and CTLA-4 alleles in Brazilian patients with primary biliary cirrhosis. J Gastroenterol Hepatol. 2003;18(9):1061-6.

39. Bittencourt PL, Palacios SA, Cancado EL, Porta G, Carrilho FJ, Laudanna AA, et al. Cytotoxic T lymphocyte antigen-4 gene poly- morphisms do not confer susceptibility to autoimmune hepatitis types 1 and 2 in Brazil. Am J Gastroenterol. 2003;98(7):1616-20.

40. Djilali-Saiah I, Ouellette P, Caillat-Zucman S, Debray D, Kohn $\mathrm{JI}$, Alvarez F. CTLA-4/CD 28 region polymorphisms in children from families with autoimmune hepatitis. Hum Immunol. 2001;62(12):1356-62.

41. Agarwal K, Czaja AJ, Jones DE, Donaldson PT. Cytotoxic T lymphocyte antigen-4 (CTLA-4) gene polymorphisms and susceptibility to type 1 autoimmune hepatitis. Hepatology. 2000;31(1):4953.

42. Petersen JS, Karlsen AE, Markholst H, Worsaae A, Dyrberg T, Michelsen B. Neonatal tolerization with glutamic acid decarboxylase but not with bovine serum albumin delays the onset of diabetes in NOD mice. Diabetes. 1994;43(12):1478-84.

43. Kaufman DL, Clare-Salzler M, Tian J, Forsthuber T, Ting GS, Robinson $\mathrm{P}$, et al. Spontaneous loss of T-cell tolerance to glutamic acid decarboxylase in murine insulin-dependent diabetes. Nature. 1993;366(6450):69-72.

44. Bretzel RG, Eckhard M, Brendel MD. Pancreatic islet and stem cell transplantation: new strategies in cell therapy of diabetes mellitus. Panminerva Med. 2004;46(1):25-42. Review.

45. Street CN, Sipione S, Helms L, Binette T, Rajotte RV, Bleackley RC, et al. Stem cell-based approaches to solving the problem of tissue supply for islet transplantation in type 1 diabetes. Int $\mathrm{J}$ Biochem Cell Biol. 2004;36(4):667-83. 